Willen Tifvany, Suzy Azeharie: Komunikasi Pesuasif Anak Vegetarian terhadap Orang Tua Nonvegetarian

\title{
Komunikasi Persuasif Anak Vegetarian terhadap Orang Tua Nonvegetarian
}

\author{
Willen Tifvany, Suzy Azeharie \\ willentifvany@gmail.com,suzya@fikom.untar.ac.id \\ Fakultas Ilmu Komunikasi Universitas Tarumanagara
}

\begin{abstract}
Vegetarian is one of the ways that human can do to start healthy lifestyle. There is process, technique, principle, and factors that supports nor hinders a message to be delivered in persuasive communication. This research is talking about persuasive communication that child to their parents and using communication theory, persuasive communication theory, interpersonal communication theory, lifestyle, and vegetarian. This research is using descriptive qualitative approach and deduction model. This research data is obtained from interview with two key informant and three informant, documentation, and study literature. From this research is known there is a difference in characteristic of interpersonal communication on the process of persuasive communication that key informant number one and key informant number two. Then, on the process of persuasive communication there is a principles. Besides that, the persuasive communication that vegetarian child do to their parents is using some techniques. The factors that support or hinder the persuasive communication process of vegetarian child do to their non-vegetarian parents can be viewed in terms of communicators and communicants. Communicators must have confidence and attractiveness in the form of self-confidence while communicants must really understand the communication message conveyed.
\end{abstract}

Keywords: interpersonal communication, persuasive communication, vegetarian

\begin{abstract}
Abstrak
Vegetarian merupakan salah satu cara yang dapat dilakukan oleh manusia untuk memulai gaya hidup sehat. Komunikasi persuasif yang dilakukan anak vegetarian terhadap orang tua nonvegetarian terdapat proses, teknik, prinsip, dan faktor-faktor yang mendukung maupun menghambat sebuah pesan untuk tersampaikan. Penelitian ini membahas tentang komunikasi persuasif anak vegetarian terhadap orang tua nonvegetarian dan menggunakan teori yang terdiri dari teori komunikasi, teori komunikasi persuasif, teori komunikasi antarpribadi, gaya hidup, dan vegetarian. Penelitian ini menggunakan pendekatan kualitatif yang bersifat deskriptif dengan model deduksi. Data penelitian ini diperoleh melalui wawancara terhadap dua orang key informan, tiga orang informan, dokumentasi, dan studi kepustakaan. Dari penelitian ini diketahui bahwa proses komunikasi persuasif yang dilakukan key informan satu dan key informan dua memiliki perbedaan karakteristik komunikasi antarpribadi. Kemudian terdapat prinsip-prinsip dalam proses komunikasi persuasif. Selain itu komunikasi persuasif yang dilakukan anak vegetarian terhadap orang tua nonvegetarian adalah dengan menggunakan beberapa teknik. Kemudian faktor-faktor yang mendukung maupun menghambat proses komunikasi persuasif anak vegetarian terhadap orang tua nonvegetarian adalah komunikator harus memiliki kepercayaan dan daya tarik yang berupa rasa percaya diri sementara komunikan harus benar-benar mengerti pesan komunikasi yang disampaikan.
\end{abstract}

Kata Kunci: komunikasi antarpribadi, komunikasi persuasif, vegetarian 


\section{Pendahuluan}

Kesehatan telah menjadi hal yang kurang diperhatikan oleh sebagian masyarakat Indonesia. Hal tersebut dapat diketahui dari data riset Kementerian Kesehatan tahun 2018, hanya 20 persen dari total masyarakat Indonesia peduli terhadap kebersihan dan kesehatan. Sebanyak 262 juta jiwa di Indonesia, hanya sebanyak 52 juta jiwa yang memiliki kepedulian terhadap kebersihan lingkungan sekitar dan dampaknya terhadap kesehatan (Riset Kesehatan Dasar, 2018).

Manusia dapat mencegah penyakit melalui gaya hidup sehat. Vegetarian dinyatakan sebagai gaya hidup sehat yang menjauhkan diri dari berbagai jenis penyakit seperti: kanker, diabetes melitus, batu ginjal, empedu, osteoporosis, dan gout (Yuliarti, 2008).

Gaya hidup vegetarian merupakan pilihan bagi setiap manusia. Ada banyak alasan bagi seseorang untuk memulai gaya hidup vegetarian. Lima alasan seseorang menjadi vegetarian yaitu: etika, pengaruh lingkungan sekitar, agama, kesehatan, dan untuk lingkungan (Rejeki, 2015). Persuasif menurut Sunarjo dan Djoenaesih S. Sunarjo merupakan usaha untuk mengubah sikap melalui penggunaan pesan, berfokus terutama pada karakteristik komunikator (Wati, 2017).

Berdasarkan uraian dan fakta di atas penulis tertarik untuk melakukan penelitian mengenai komunikasi persuasif yang dilakukan anak vegetarian terhadap orang tuanya yang bertujuan untuk mengetahui proses komunikasi persuasif yang dilakukan.

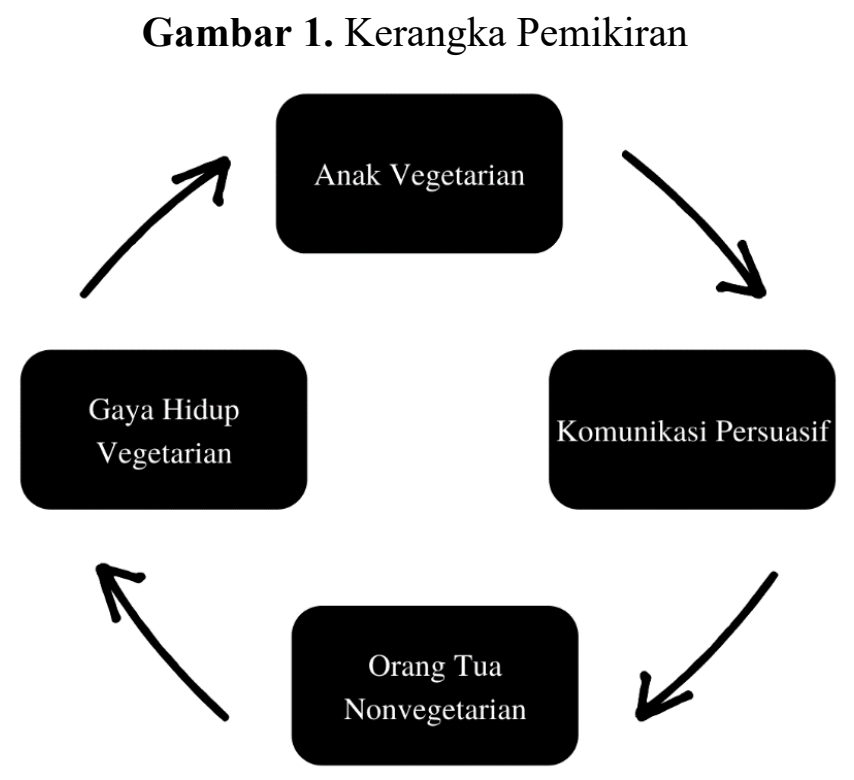

Pada Gambar 1 merupakan kerangka pemikiran yang digunakan oleh penulis yaitu anak yang terlebih dahulu memulai vegetarian di keluarganya. Dalam mempengaruhi orang tua nonvegetarian, anak vegetarian melakukan komunikasi persuasif tentang gaya hidup vegetarian. Dalam penelitian ini penulis membatasi ruang lingkup penelitian. Penelitian dilakukan pada dua orang anak vegetarian yang melakukan komunikasi persuasif terhadap orangtuanya. Dengan topik penelitian Studi Komunikasi Persuasif Anak Vegetarian Terhadap Orang Tua Nonvegetarian, maka yang menjadi obyek penelitian ini adalah analisa komunikasi persuasif yang 
Willen Tifvany, Suzy Azeharie: Komunikasi Pesuasif Anak Vegetarian terhadap Orang Tua Nonvegetarian

dilakukan anak vegetarian dan subyek penelitian adalah anak vegetarian yang melakukan komunikasi persuasif

Berdasarkan latar belakang penelitian di atas maka tujuan penelitian ini adalah untuk mengetahui proses komunikasi persuasif yang dilakukan anak vegetarian terhadap orang tua nonvegetarian. Selain itu juga untuk mengetahui faktor-faktor yang menghambat dan mendukung bagi anak vegetarian melakukan komunikasi persuasif terhadap orang tua nonvegetarian.

\section{Metode Penelitian}

Pada penelitian ini penulis menggunakan metode penelitian kualitatif secara deskriptif dengan model deduksi yang menjadikan teori sebagai alat penelitian utama sejak memilih dan menemukan masalah, membangun hipotesis hingga proses pengujian data atau analisa data. Penulis mengumpulkan data dengan melakukan wawancara dengan narasumber yaitu dua orang key informan dan tiga orang informan, dokumentasi, dan studi kepustakaan. Narasumber penelitian ini adalah sebagai berikut:

1. Key informan pertama adalah Rio Sanjaya Putra yang berusia 21 tahun. Ia lahir di Jakarta pada tanggal 10 Desember 1999 dan menjadi vegetarian pertama di keluarganya. Ia memulai gaya hidup vegetarian sejak 13 Januari 2018 saat berada di bangku SMA. Saat ini Rio merupakan mahasiswa semester lima Fakultas Ilmu Komunikasi Universitas Tarumanagara.

2. Key informan kedua adalah Julius Wijaya berusia 28 tahun. Julius menjalani vegetarian di keluarganya sejak tahun 2010. Saat ini Julius merupakan akuntan senior di perusahaan swasta Obisidian Stainless Steel.

3. Informan pendukung pertama adalah Janice Suwandi. Ia lahir di Jakarta pada tanggal 15 Maret 2000. Janice sudah memulai vegetarian sejak berada dalam kandungan. Saat ini Janice merupakan mahasiswi semester lima Fakultas Ilmu Komunikasi Universitas Tarumanagara.

4. Informan pendukung kedua adalah Katia Shiffana. Katia merupakan pemilik dari katering makanan vegan@veganbaby.id. Ia sudah memulai gaya hidup vegan sejak tahun 2017.

5. Informan pendukung ketiga adalah Lisa Zhang berusia 32 tahun. Lisa merupakan seorang aktivis Indonesia Vegetarian Society (IVS) sejak tahun 2015. Selain itu ia juga seorang pembawa acara dan pengusaha.

Kemudian teknik analisis data dalam penelitian ini adalah dengan melakukan reduksi data, penyajian data, dan penarikan kesimpulan.

\section{Hasil Temuan dan Diskusi}

Berdasarkan hasil wawancara dengan Rio, komunikasi persuasif yang ia lakukan tidak dilakukan hanya melalui tatap muka saat berbincang atau makan bersama saja namun melalui media pesan instan Whatsapp yang dilakukan dengan mengirimkan sebuah video kepada orang tuanya mengenai hewan yang disembelih untuk dijadikan konsumsi manusia. Menurut Rio, dengan mengirimkan video akan membuat orang tertarik daripada hanya mengirimkan artikel. Proses penyembelihan menurut Rio akan menghasilkan bau tidak sedap pada daging karena adanya pencemaran mikrobiologi dan terjadinya pembentukan gas-gas seperti ammonia yang dapat mempengaruhi lingkungan. 
Hal ini sesuai dengan Judy C. Pearson yang dikemukakan oleh Sasa Djuarsa Sendjaja yang mengatakan komunikasi antar pribadi mencakup aspek-aspek isi pesan dan hubungan antar pribadi. Isi pesan yang ingin disampaikan Rio melalui video tersebut diperlihatkan ke ibunya yang melibatkan hubungan antarpribadi sebagai ibu dan anak karena alasan sang anak ingin orang tuanya tetap sehat dengan menjalani gaya hidup vegetarian mengingat usianya yang sudah di atas 50 tahun.

Dari hasil wawancara dengan Julius, salah satu proses komunikasi yang dilakukannya melalui panggilan video dengan menggunakan media Skype karena sedang sibuk kuliah di Jakarta. Panggilan video ini dilakukan satu hingga dua kali dalam satu bulan. Pada panggilan video yang dilakukan dengan orang tuanya terdapat kakak perempuannya yang sudah menjalani vegetarian sebelum dirinya. Kakak perempuannya tinggal di dalam satu rumah dengan orang tuanya dan membantu dirinya melakukan komunikasi persuasif sehingga dalam jangka waktu satu bulan orang tuanya yakin dan menjalani gaya hidup vegetarian. Hal ini sesuai dengan Judy C. Pearson yang ditulis oleh Sasa Djuarsa Sendjaja yang mengatakan bahwa komunikasi antar pribadi mensyaratkan kedekatan fisik antar pihak yang berkomunikasi. Oleh karena itu, komunikasi persuasif dapat berhasil karena bantuan kakak perempuannya.

Menurut hasil wawancara dengan Rio terungkap bahwa orang tuanya percaya dengan pendapat jika tidak makan daging maka akan kekurangan protein, vitamin dan gizi. Selain itu, reaksi orang tua pertama kali ketika dirinya melakukan komunikasi persuasif tentang vegetarian adalah bersikap tidak peduli dengan cara tidak memperhatikan dan hal yang sama dikatakan oleh Julius bahwa ayahnya juga pernah menghindar saat dilakukan komunikasi persuasif oleh Julius. Ayahnya menghindar dengan cara tidak menanggapi pembicaraan. Hal ini membuktikan bahwa orang tua Rio sebagai pendengar mencari informasi yang mendukung opini dan kepercayaan mereka sehingga sesuai dengan prinsip pemaparan selektif menurut Stephen W. Littlejohn dan David M. Jabusch, dalam Joseph A. DeVito.

Pada prinsip partisipasi khalayak, Rio menyatakan bahwa orang tuanya mengatakan bahwa hanya sedikit pilihan makanan vegetarian yang dapat ditemukan di restoran-restoran. Rio lalu memberikan jawaban pada aspek yang dikuasainya yaitu manfaat yang dia rasakan sendiri dari mengubah pola hidup ke vegetarian, sehingga pilihan makanan di restoran tidak terlalu mempengaruhi dirinya. Hal yang sama dikatakan oleh orang tua Julius yang juga berpartisipasi secara aktif dengan mendengarkan pendapat dan memberikan argumen yang dibuktikan dengan pernyataan sedikitnya variasi masakan berbahan vegetarian yang bisa dimasak oleh ibunya yang kemudian dibalas Julius dengan argumen mengenai vegetarian dari segi spiritual maupun kesehatan dan juga pengetahuan lainnya tentang vegetarian. Hal ini membuktikan bahwa orang tuanya berpartisipasi secara aktif dengan mendengarkan pendapat dan memberikan argumen.

Kemudian terdapat prinsip inokulasi yang sesuai dengan argumentasi yang disampaikan Rio saat dirinya melakukan komunikasi persuasif dan orang tuanya mengatakan tidak mengonsumsi makanan yang bersumber dari hewani akan menyebabkan kekurangan gizi. Ia kemudian memberikan argumentasi yang sudah dipersiapkan yaitu seorang sepupunya yang berusia lima tahun dan sudah menjalani gaya hidup vegetarian, guna meyakinkan orang tuanya. Julius juga sudah menyiapkan argumentasi saat orang tuanya mengatakan vegetarian tidak berguna dan berpendapat orang yang vegetarian pada umumnya tidak bertenaga. Ia berargumen 
Willen Tifvany, Suzy Azeharie: Komunikasi Pesuasif Anak Vegetarian terhadap Orang Tua Nonvegetarian

bahwa dua orang di keluarga besarnya sudah menjalani gaya hidup vegetarian sebelum dirinya.

Teknik yang digunakan oleh Rio yaitu menggunakan teknik asosiasi yang menyajikan pesan bahwa pentingnya menjaga kesehatan dengan gaya hidup yang sehat. Salah satunya dapat dilakukan dengan memulai gaya hidup vegetarian dengan memanfaatkan situasi pandemi Covid-19 yang sedang menarik perhatian orang tuanya. Teknik integrasi yang diketahui dari komunikator yaitu Rio yang melakukan pembicaraan secara verbal kepada orang tuanya mengenai pendapat pribadinya berdasarkan informasi yang ia dapatkan. Teknik ganjaran yang dibuktikan dari pembicaraan jika menjalani gaya hidup vegetarian maka akan mendapatkan keuntungan-keuntungan diantaranya yaitu badan yang menjadi lebih segar, emosi yang menjadi stabil karena tidak mengonsumsi hal-hal yang berhubungan dengan darah dan jarang sakit. Kemudian teknik red-herring yaitu mengenai kesulitan melakukan puasa konsumsi daging ke pengetahuan yang diketahuinya dari membaca jurnal dan artikel di internet yaitu hewan dan lingkungan akan lebih baik jika secara perlahan manusia mengurangi konsumsi tersebut.

Dari hasil wawancara dengan Julius, proses komunikasi persuasif yang dilakukannya harus memperhatikan nada bicara yang bersahabat dan tidak berbicara terlalu cepat kepada orang tua juga sesuai dengan teknik tataan yang merupakan upaya menyusun pesan komunikasi sedemikian rupa sehingga menarik untuk didengar atau dibaca serta membuat pendengar untuk melakukan seperti disarankan oleh pesan tersebut (Effendy, 2015: 23).

Teknik red-herring juga digunakan oleh Julius yang memenangkan argumentasi mengenai perasaan tidak yakin orang tuanya untuk menjalani gaya hidup vegetarian yang merupakan perjanjian yang tidak boleh diingkar dengan Tuhan. Julius mengalihkan argumentasi tersebut dengan mengatakan bahwa orang tuanya mampu melakukannya karena dirinya dan kakak perempuannya sudah menjalaninya sehingga orang tuanya pasti bisa melakukannya.

Faktor-faktor yang mendukung dan menghambat dari segi komunikator yaitu Rio telah menunjukkan dirinya memiliki kepercayaan dan daya tarik yaitu rasa percaya diri yang ia bangun dari penolakan yang diterimanya saat awal melakukan komunikasi persuasif. Sedangkan Julius yang daya tariknya terlihat dari ekspresi wajah serius, mata berbinar dan cara penyampaian yang yakin. Dari segi komunikan, dalam hal ini orang tuanya sadar saat mereka mengambil keputusan yang bersangkutan dengan kepentingan pribadi mereka.

Menurut pernyataan Lisa bahwa komunikator sudah merasakan manfaat dari gaya hidup vegetarian. Kemudian dia merasa sudah saatnya harus memberitahukan kabar baik tentang gaya hidup vegetarian kepada orang lain. Ia juga menambahkan bahwa komunikator memiliki rasa peduli terhadap orang-orang di sekitarnya dan komunikator merasakan penting bagi orang-orang di sekitarnya untuk mengetahui akan manfaat dari menjalani gaya hidup vegetarian.

Hal tersebut sesuai dengan yang dinyatakan oleh key informan Rio yang ingin memberitahukan manfaat yang ia dapatkan setelah menjalani gaya hidup vegetarian ke orang tuanya mengingat usia orang tuanya yang sudah mencapai 50 tahun.

Selain itu dari penelitian ini diketahui bahwa Julius yang melakukan komunikasi persuasif dengan mengedepankan aspek agama yang terlihat dari jangka waktu orang tuanya yang sudah terpersuasi dalam satu bulan. Oleh karena itu, komunikator yang melakukan komunikasi persuasif dengan mengedepankan aspek 
agama yaitu ajaran yang melarang konsumsi hewan akan lebih cepat terpengaruh pada komunikan yang menyebabkan komunikan mengikutinya.

\section{Simpulan}

Proses komunikasi yang dilakukan anak vegetarian dilakukan secara rutin dua minggu sekali di meja makan, ruang tamu, dan media pesan instan Whatsapp yang dilakukan dari awal tahun 2018 hingga saat ini. Proses tersebut didasari dengan karakteristik komunikasi antar pribadi mencakup aspek-aspek isi pesan dan hubungan antar pribadi. Poses komunikasi juga dilakukan dengan panggilan video melalui media Skype yang dibantu dengan kehadiran kakak perempuannya pada panggilan video. Proses tersebut didasari dengan karakteristik komunikasi antar pribadi mensyaratkan kedekatan fisik antar pihak yang berkomunikasi.

Prinsip-prinsip komunikasi persuasif yang dilakukan anak vegetarian terhadap orang tua nonvegetarian adalah prinsip pemaparan selektif yang menunjukkan orang tua nonvegetarian menghindari perbedaan informasi tentang vegetarian yang disampaikan oleh anak vegetarian dengan sikap dan pendapat yang mereka percayai benar. Prinsip partisipasi khalayak yang menunjukkan komunikasi persuasif yang dilakukan anak vegetarian berhasil karena adanya partisipasi dari orang tua nonvegetarian dan prinsip inokulasi yang ditunjukkan anak vegetarian yaitu telah mempersiapkan berbagai argumentasi tentang keuntungan-keuntungan vegetarian karena orang tua nonvegetarian telah menyiapkan argumen untuk menentang anak vegetarian.

Proses komunikasi persuasif yang dilakukan anak vegetarian terhadap orang tua nonvegetarian adalah dengan menggunakan teknik asosiasi yang menuangkan pada suatu peristiwa yang sedang menarik perhatian komunikan mengenai kondisi pandemi Covid-19 sehingga penting untuk menjaga kesehatan. Teknik integrasi yang dilakukan dengan menerima argumen orang tuanya tentang sedikitnya pilihan makanan vegetarian yang dapat ditemukan di restoran-restoran dengan memahami maksud orang tuanya terlebih dahulu kemudian dilanjutkan dengan penjelasan lebih lanjut mengenai manfaat vegetarian. Teknik ganjaran yang dilakukan dengan memberitahukan keuntungan berdasarkan pengalaman pribadi anak vegetarian setelah menjalani gaya hidup vegetarian yaitu tubuh tetap sehat jika hanya mengonsumsi nabati tanpa harus mengonsumsi hewani. Teknik tataan yang dilakukan dengan memperhatikan nada bicara yang bersahabat dan tidak berbicara terlalu cepat ketika melakukan komunikasi persuasif dan teknik red-herring yang dilakukan dengan mengalihkan sedikit demi sedikit argumen ke aspek yang dikuasai key informan tentang vegetarian.

Faktor-faktor yang mendukung maupun menghambat proses komunikasi persuasif anak vegetarian terhadap orang tua nonvegetarian dapat ditinjau dari segi komunikan maupun komunikator. Komunikan harus benar-benar mengerti pesan komunikasi yang disampaikan dan komunikator harus memiliki kepercayaan dan daya tarik.

Komunikator atau anak vegetarian melakukan komunikasi persuasif kepada orang tuanya dengan cara memberitahukan keuntungan-keuntungan menjadi vegetarian melalui argumen tentang vegetarian karena alasan yang sama dengan faktor yang mempengaruhi komunikator melakukan vegetarian. 
Willen Tifvany, Suzy Azeharie: Komunikasi Pesuasif Anak Vegetarian terhadap Orang Tua Nonvegetarian

Komunikator yang melakukan komunikasi persuasif dengan mengedepankan aspek agama yaitu ajaran yang melarang konsumsi hewan akan lebih cepat terpengaruh pada komunikan yang menyebabkan komunikan mengikutinya.

Bagi anak yang melakukan komunikasi persuasif terhadap orang tuanya tentang vegetarian, penulis menyarankan sebagai komunikator harus memiliki kepercayaan dan daya tarik berupa rasa percaya diri sehingga dapat menjelaskan dengan percaya diri dan bersungguh-sungguh serta memastikan pesan komunikasi yang disampaikan benar-benar dimengerti oleh komunikan, dan juga menerapkan teknik-teknik persuasi yang sesuai agar tujuan dan sasaran komunikasi persuasif tercapai. Selain itu komunikasi persuasif yang dilakukan anak vegetarian terhadap orang tuanya juga harus diberikan jeda saat bicara agar komunikasi persuasif lebih natural.

\section{Ucapan Terima Kasih}

Penulis mengucapkan terima kasih kepada lima orang narasumber yang telah bersedia dan memberikan kerjasama selama proses penelitian ini berlangsung. Selain itu penulis juga ingin mengucapkan terima kasih kepada dosen pembimbing yang sudah bersedia meluangkan waktu dan membimbing penulis.

\section{Daftar Pustaka}

Badan Penelitian dan Pengembangan Kementrian Dalam Negeri. (9 Oktober 2020). Riset: Kesadaran Masyarakat Indonesia akan Kebersihan Masih Rendah.. Diakses dari https://litbang.kemendagri.go.id/website/riset-kesadaranmasyarakat-indonesia-akan-kebersihan-masih-rendah/

Rejeki, S. (2015). Ya, Saya Vegetarian. Yogyakarta: Familia.

Wati, F. F. (2017, April). Kemampuan Komunikasi Persuasif Pengelola Museum Provinsi Sulawesi Tengah. Jurnal online Kinesik, 4(1), 81-91.

Yuliarti, N. (2008). Pilih Vegetarian atau Non Vegetarian. Jakarta: Gramedia Pustaka Utama. 